
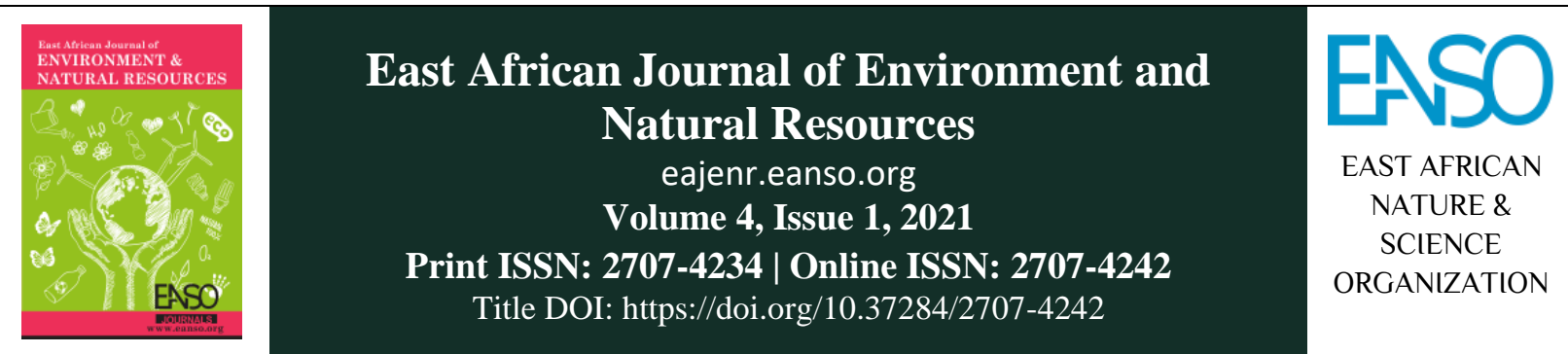

Original Article

\title{
Environmental and Socio-economic Impact Assessment of Stone Quarrying in Tororo District, Eastern Uganda.
}

\author{
Remigio Turyahabwe ${ }^{1}$, Joyfred Asaba ${ }^{2}$ Andrew Mulabbi ${ }^{2 *}, \&$ Christopher Osuna ${ }^{1}$ \\ ${ }^{1}$ Busitema University, P. O. Box 236, Tororo, Uganda. \\ ${ }^{2}$ Muni University, P. O. Box 725, Arua, Uganda. \\ ${ }^{3}$ Kyambogo university Kampala Uganda P. O. Box 1 Kyambogo, Kampala Uganda. \\ *Correspondence email: mulabbiandrew@yahoo.com.
}

Article DOI: https://doi.org/10.37284/eajenr.4.1.445

\section{Date Published: ABSTRACT}

22 October 2021 The study aimed at assessing the environmental and socio-economic impact of stone quarrying in Tororo district. To achieve this, we used questionnaires, Keywords: interviews and focused group discussions, where the information obtained was confirmed by field observations. The data was analysed using simple descriptive statistics like percentages, tables and graphs. Results indicated that, Terrestrial Ecosystem,

Main Quarry,

Employment, stone quarrying did more harm than good on the biophysical environment as it came with terrestrial ecosystem degradation as reported by $65 \%$, water quality deterioration as reported by $34 \%$ as well as deafening noise and air pollution as indicated by $100 \%$ of the total respondents. Socio-economic analysis Accidents, indicated that benefits of stone quarrying outweighed costs. For example, Scenery Deformation. $100 \%$ of respondents indicated that employment arose from stone quarrying and $79 \%$ stated that, standards of living have been elevated by the activity. The district local government realizes local revenue from the activity. The activity is however associated with accidents and subsequent loss of lives and physical body damages due to collapsing caves of quarries. It was therefore concluded that, Tororo district environment office should monitor the quarrying activities to avoid leaving open pits and caves that are dangerous to lives of people at quarry sites.

\section{APA CITATION}

Turyahabwe, R., Asaba, J., Mulabbi, A., \& Osuna, C. (2021). Environmental and Socio-economic Impact Assessment of Stone Quarrying in Tororo District, Eastern Uganda. East African Journal of Environment and Natural Resources, 4(1), 1-14. https://doi.org/10.37284/eajenr .4 .1 .398

\section{CHICAGO CITATION}

Turyahabwe, Remigio, Joyfred Asaba, Andrew Mulabbi and Christopher Osuna. 2021. "Environmental and Socio-economic Impact Assessment of Stone Quarrying in Tororo District, Eastern Uganda". East African Journal of Environment and Natural Resources 4 (1), 1-14. https://doi.org/10.37284/eajenr.4.1.445.

1 | This work is licensed under a Creative Commons Attribution 4.0 International License. 


\section{HARVARD CITATION}

Turyahabwe, R., Asaba, J., Mulabbi, A., \& Osuna, C. (2021) "Environmental and Socio-economic Impact Assessment of Stone Quarrying in Tororo District, Eastern Uganda", East African Journal of Environment and Natural Resources, 4(1), pp. 1-14. doi: 10.37284/eajenr.4.1.445.

\section{IEEE CITATION}

R. Turyahabwe., J. Asaba., A. Mulabbi., \& C. Osuna, "Environmental and Socio-economic Impact Assessment of Stone Quarrying in Tororo District, Eastern Uganda”, EAJENR, vol. 4, no. 1, pp. 1-14, Oct 2021.

\section{MLA CITATION}

Turyahabwe, Remigio, Joyfred Asaba, Andrew Mulabbi \& Christopher Osuna. "Environmental and Socio-economic Impact Assessment of Stone Quarrying in Tororo District, Eastern Uganda". East African Journal of Environment and Natural Resources, Vol. 4, no. 1, Oct 2021, pp. 1-14, doi:10.37284/eajenr.4.1.445.

\section{INTRODUCTION}

The term quarrying originates from the Latin word 'Quadraria' which means a place where stones are extracted. Stone quarrying is therefore the extraction of stones or slate from an open surface quarry (Langer and Kolm, 2001). Despite the fact that agriculture has remained the key player in socio-economic development of many countries, stone quarrying too plays a pivotal role not only in poverty alleviation but also in local community livelihood improvement in most developed and developing countries. This is more so in rural and peri-urban areas where these two activities take place.

Quarrying contributes to economic growth as it involves both genders in different parts of the world (Langer, 2001). Rapid change in building and infrastructure development has increased demand for rock-based construction materials and hence increase in the quarry activities. It has increased availability of construction material in form of stone aggregates, stone dust, cement and building lime. Stone quarrying, being an economic activity is associated increased tax base for the government, better standards of living, increased incomes, employment opportunities for the local population (Tanyaradzwa, 2010).

Quarrying on the other hand has environmental and health effects. It is estimated that some 4 million people in the whole world die each year from acute respiratory problems in developing countries, for the most part being aggravated by environmental pollution emanating from quarrying, sandblasting and emission of dangerous chemicals (Langer, 2001). A report by the World Bank working group on environmental sustainability reveals that occupations such as lumbering, mining, quarrying, and sandblasting degrade the environmental and worsen the plight of the poor (Brajesh, 2008).

In most African countries, the most undesirable environmental outcomes such as soil erosion and loss of rich biodiversity are largely attributed to active and abandoned quarry sites (Mwangi, 2014). Such problems escalate due to lack of environmental awareness while operating mines. (Langer, 2009). Quarrying distorts nature by disturbing unique habitats, significant alteration of topography and unchecked disruption of basic ecological relations.

In Zimbabwe, the benefits of black granite quarrying are employment and creation of infrastructural development and revenue generation. One of the major economic benefits of black granite quarrying in Mutoko district is that of employment creation. The 13 quarrying companies have a total work force of about 3,000 workers $80 \%$ of who are from within the district and the remaining $20 \%$ from other parts of the country. This shows that most of the job opportunities have been taken up by the people from the district. Most of the activities can absorb the unskilled labour thereby creating employment for the less educated people within the locality (Tanyaradzwa, 2010).

The East African quarry industry is dominated by Kenya's cement giants Athi River Mining Company (ARM). The group is investing heavily in limestone quarrying for example, they plan to invest in Kitui county about 25 million United States Dollar Other large quarrying companies are those mining limestone for cement for example Hima cement, Masekeru and Dura all owned by the French cement giants, Lafarge (Wells, 2000). In Kenya, both rural 
and urban dwellers depend on day-to-day gathering and breaking of stones for sale. Wells (2000) identifies small-scale stone extraction in rural Kenya as a major source of livelihood in spite of the dangers it poses to the environment and the other livelihood activities such as farming.

Uganda's largest building stone quarry, (Namubiru stone quarry) is located in Mukono 6 kilometres from Mukono town and it occupies 30 acres' land with a production capacity of 80 tons per day and also produces products like asphalt for road construction in addition to ordinary building stones (Ogwang, 2019). Birabwa (2006) observed that poor individuals and households seek livelihood alternatives from small-scale stone extraction especially those close to the hills of Kasenge in Uganda. Though the negative repercussions of the quarry occupation far outweigh the positive impacts, residents find the occupation as the only livelihood alternative. The occupation attracts the adult population with mouths to feed but with limited access to cultivable land (Birabwa, 2006).

In the Eastern Region of Uganda and Tororo District in particular, commercial extraction of black igneous, Limestone, dolomite, marble and the carbonate rocks has led to land degradation and desertification through destruction of trees and grass mostly indigenous in nature. In spite of this, quarrying continues to be a major occupation for most poor people living in rural areas across the globe. Increasing demand for stone products, particularly in the construction industry, has led to the development of extensive quarrying operations in Tororo District. The establishment and expansion of stone quarrying activities in Tororo has transformed the district into an important cement industrial region of the country with about four cement factories including but not limited to Hima, Tororo and Simba, all in one district local area. While no comprehensive research on the impacts of stone quarrying on bio-physical environment and socio-economic development of Tororo district has been conducted, isolated reports by various stakeholders, including communities around quarry sites and local council leaders have pointed to various negative impacts. Other stakeholders have also questioned whether despite the direct visible socio-economic gains from the activity, there are any indirect and long-term negative impacts that current quarrying operations could be bringing to the district in future

The presence of the various valuable rock types in Tororo could act as a springboard for socioeconomic development. However, this can only be best understood by, first establishing the impacts of current stone quarrying operations on the biophysical environment and socio-economic development of the area, which, to date, are not comprehensively known, and then come up with measures to enhance the positive impacts and reduce or, where possible, eliminate the negative impacts. This study sought to examine the socioeconomic and biophysical environmental impacts of stone quarrying in Tororo District. It also suggested some recommendations in order to ensure that stone quarrying contributes towards the sustainable development of the district.

\section{MATERIALS AND METHODS}

\section{Description of the Study Area}

Tororo district is located in Eastern Uganda, bordered by Kenya on the eastern side, Busia and Namayingo to the south as well as Mbale and Budaka districts to the west. The mining sites selected were petta for artisanal stone quarrying located in Petta sub-county and Tororo town quarry site as the main commercial quarrying site mainly for cement production located in the Tororo municipality western division (Figure 1). Generally, Tororo district is a plateau slightly slanting towards the west. The landscape is however punctuated by exposed rocks in Ayago, Ramogi, Mbula and Petta central and the main Tororo rockthe volcanic plug standing in the Tororo town. 
Figure 1: Tororo stone quarrying sites

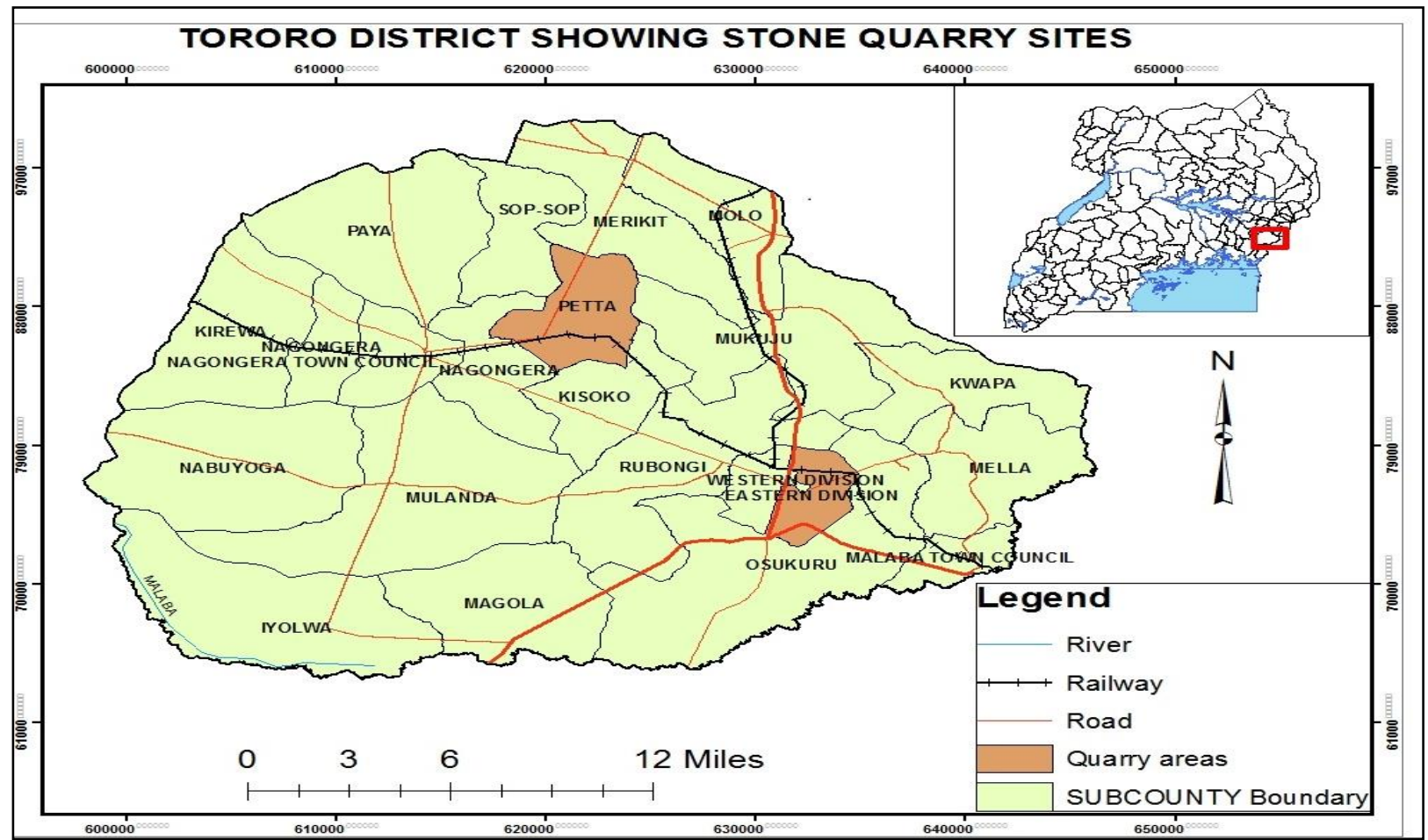

The upland areas of Kanangi, Ramogi are well drained and streams of water flow from these areas towards the lowland in the west. There are a few streams for example sourced at Ayago flowing through Petta central where it divides its course into two distributaries. One of the distributaries flows westwards to Sa Pa'jakongo in Nagongera Sub County via Pakoi lowlands and the other flows northwards to $\mathrm{Sa} \mathrm{Pa}$ 'Kisa, wetland. Tororo district is a savannah region characterized by shrubs, grassland and scattered trees. The swamps are covered with swampy vegetation. Most of the swampy vegetation has however been cleared to provide land for agriculture and settlement the classic example is found in Opeta swamp in Ayago, the Pakoi swamp and so on. The area is characterized by bi modal rain fall but with long drought spells than rainy season.

Tororo main quarry site has a geology dominated by sedimentary rocks especially at the lowlands more especially sandstone in the area of Landi in Petta while Petta quarry site is characterized black granite rocks residues of inselbergs. The soils are dominated by Paraferrallitic soils derived in situ from igneous and metamorphosed igneous parent rock. These are sandy soils which are naturally infertile due to low nutrient reserves and little capacity to retain the nutrients due to low levels of clay and organic matter (Thompson \& Purves, 1978 as cited in Makuvaro et al., 2014). The major economic activity for the 561,000 persons at a density of 526.2 persons $/ \mathrm{km}^{2}$ in Tororo District is peasant farming, trade and quarrying.

\section{Data Collection}

We collected data from primary and secondary sources. Secondary data sources included internet, text books and journal articles. Primary data was collected from the workers at quarry sites and surrounding local households using questionnaires, interviews and field observations to gain insights about the nature of the impact of stone quarrying on the bio-physical environment and socio-economic development of Tororo district and how best to maximize the positive benefits and minimize negative impact from stone quarrying. We trained and recruited local assistants (10 per site) to assist in the administration of questionnaires to address the specific needs of this study. Questionnaires to households were administered to mature people above 18 years of age. The questionnaires targeted information relating to socio-demographic data, job

4 | This work is licensed under a Creative Commons Attribution 4.0 International License. 
description, area of origin, working conditions, includes remuneration and workplace health and safety, and marital status. The socio-economic and biophysical benefits and costs of black granite quarrying, and how best to maximize and minimize them, respectively, was also part of questionnaire content.

The study adopted purposive, clustered and random sampling designs. The study considered the two quarry sites (Tororo main quarry and Petta Artisanal quarry sites) as clusters. In cluster 1 (Tororo main quarry site), $100(70 \%)$ of the estimated workers and $25(50 \%)$ of the estimated households were sampled for study, while in cluster 2 (Petta quarry site), $100(80 \%)$ estimated quarry workers and 15 $(67 \%)$ of the estimated households were sampled in our study. Households and individuals at sites were selected randomly. Interview and focus group discussions were held with the categories of persons mentioned above to gain insights about opinions, attitudes and knowledge of local communities the impact of stone quarrying on bio-physical environment and socio-economic development of their area. We used field observations to relate and confirm information accuracy from questionnaire and interview responses. Questionnaires, interviews, discussions were made between December 2020 and June 2021 and responses were translated into English language. The households considered were those that were found within a range of 10-16 km radius from the fringes of the respective quarry sites.

Structured interviews were held with a representative from each local village council 1 community development officer of the sub-county visited, school heads for surrounding schools, and, lastly workers at quarry sites. Information sought through structured interviews was combined with that generated through the questionnaire surveys and observations.

\section{Data Analysis}

Data obtained from questionnaires, discussions, interviews and field observations were analysed qualitatively and quantitatively. Statistical analyses took the form of simple descriptive statistics that is, frequencies and percentages with the findings presented in graphs and tables.

\section{RESULTS}

\section{Environmental Impact Assessment of Stone Quarrying in Tororo District}

Our study revealed that stone quarrying in Tororo district has caused both costs and benefits, but on a balance, the environmental impacts/costs outweighed the benefits. These were summarized in Table 1 and displayed visually in Figure 2.

Table 1: Environmental impact assessment of stone quarrying in Tororo district

\begin{tabular}{lll}
\hline Response & f & \% \\
\hline Costs & & 65 \\
Terrestrial ecosystem degradation & 130 & 34 \\
Deterioration of water quality. & 68 & 50 \\
Scenery deformation & 100 & 29 \\
Drying up of wells and boreholes & 57 & 25 \\
Cave and sinkhole formation & 50 & 100 \\
Noise and air pollution & 200 & \\
\hline Benefits & & 20 \\
\hline Creation of new habitats & 39 & \\
\hline
\end{tabular}

5 | This work is licensed under a Creative Commons Attribution 4.0 International License. 
Figure 2: Environmental impacts of stone quarrying in Tororo district

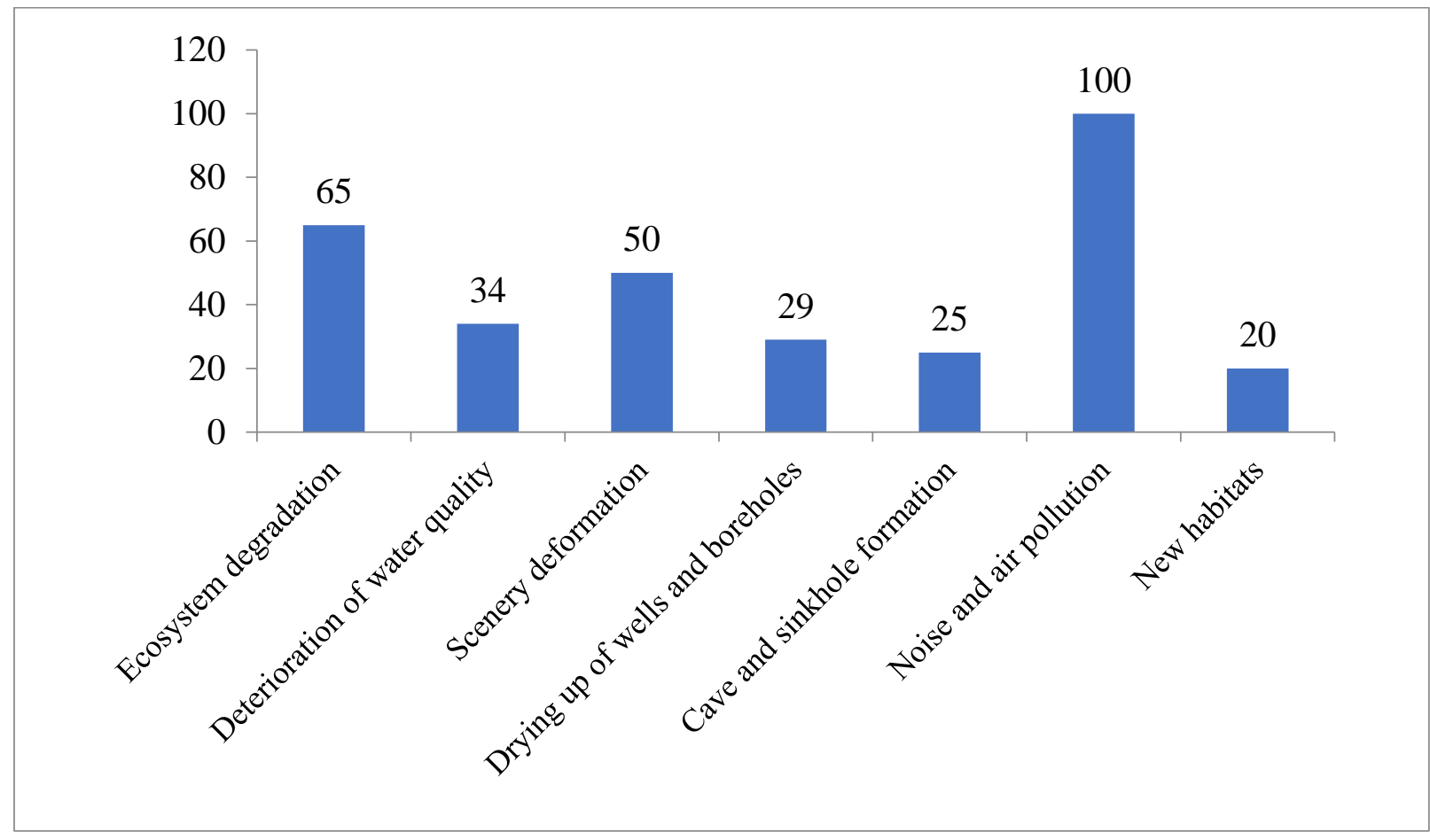

Stone quarrying came with terrestrial ecosystem degradation. This was the second most dominantly reported cost of stone quarrying in Tororo $(65 \%)$ as shown in Table 1 and Figure 2. Removal of vegetation cover to unearth the rocks for quarrying was followed by destruction of biota and biota micro habitats. At the Tororo main quarry site, stone quarrying has encroached on part of the conserved famous Tororo rock (the most massif solitary volcanic plug-in eastern Africa) by removing grass, shrub, thicket and tree vegetation cover which were habitats for monkeys (both vervet and colubus species), macroinvertebrates like worms as well as mole rats. Some of these have become extinct while some monkeys and mole rats have been seen stray in people's homes and gardens since their habitats were degraded.

Based on Figure 2, 34\% of the respondents indicated that, Water quality deterioration in their wells was attributed to stone quarrying since the activity came with increased sedimentation of wells and springs where local people abstract water for domestic use. As a result of rock blasting, the remains of loose rock particles, metallic rock ores (aluminium, iron etc), oil from machines that spill on ground are carried by rain water down slope vertically and or horizontally (through percolation, run off and or ground flow) to the wells and springs. Addition of these pollutants increase turbidity, conductivity, TDS and TSS which in the long run have resulted into diseases to humans in these quarry regions.

Stone quarrying was found to be associated with scenery deformation and loss of scenic beauty of Tororo hills. Part of the magnificent Tororo rock (volcanic plug) and famous Osukuru hills have been deformed and reduced to quarry depressions. These depressions have not been back-filled even in parts where quarrying ceased (Plate 1). These man-made depressions are filled by rain water during wet season. The rain water-filled depressions are not only habitats of disease vectors but have also been dangerous to humans especially children who accompany their parents to quarry sites. This was said to have hurt $50 \%$ of respondents (Table 1).

6 | This work is licensed under a Creative Commons Attribution 4.0 International License. 
East African Journal of Environment and Natural Resources, Volume 4, Issue 1, 2021

Article DOI: https://doi.org/10.37284/eajenr.4.1.445

Plate 1: After deforming the landscape, no attempts were made to back-fill the depression

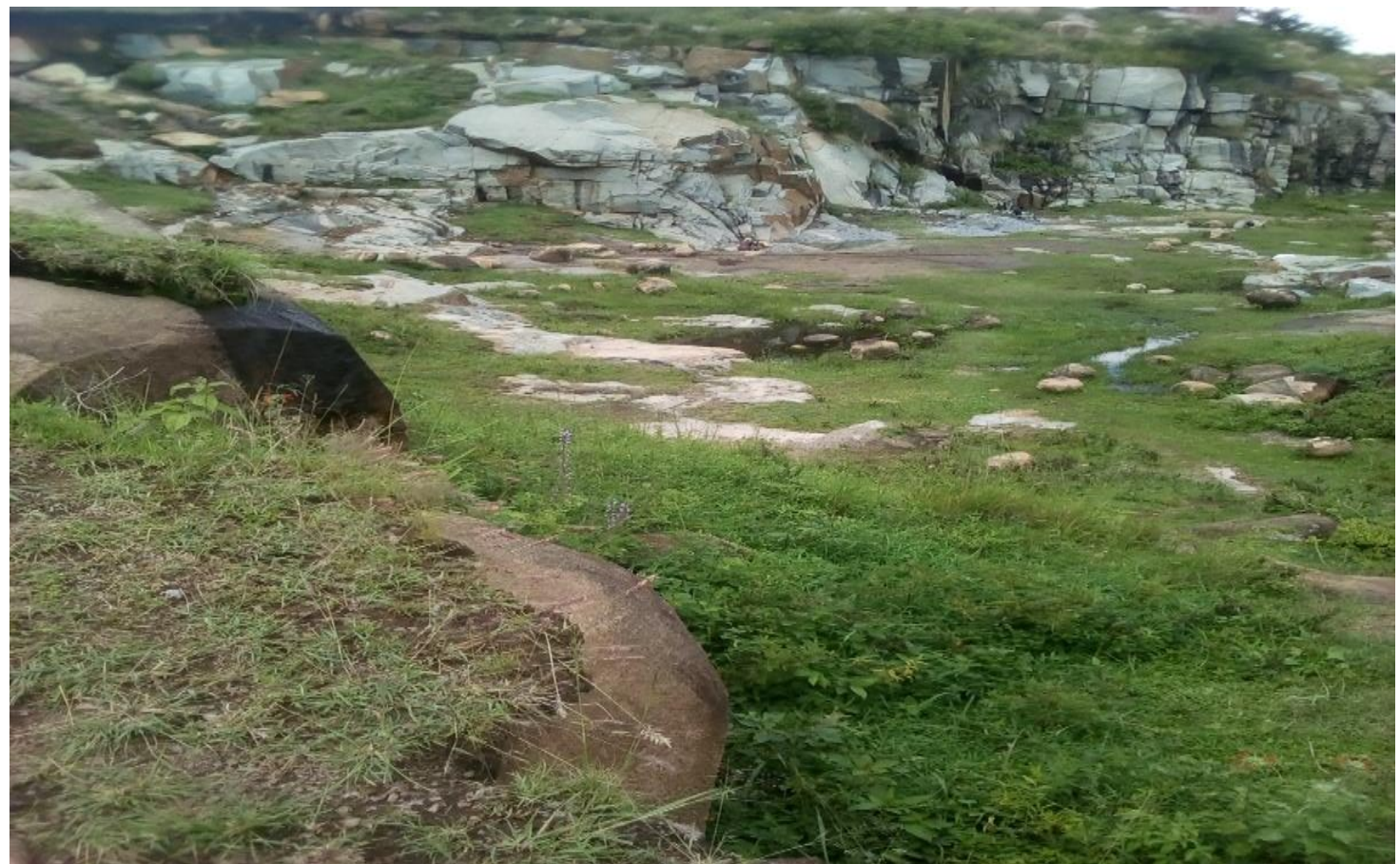

Stone quarrying has come with desiccating and drying up of a number of boreholes and wells in Tororo district. Stone quarrying has been said to have intruded artesian aquifers and flowing wells (water table) in the regions where these two quarry sites are found. This was anticipation was based on the drying up of wells and boreholes and wilting of grass and trees in the surrounding areas even when they were not cut as shown in Plate 2.

\section{Plate 2: A drying well down slope of a quarry site at petta attributed to stone quarrying}

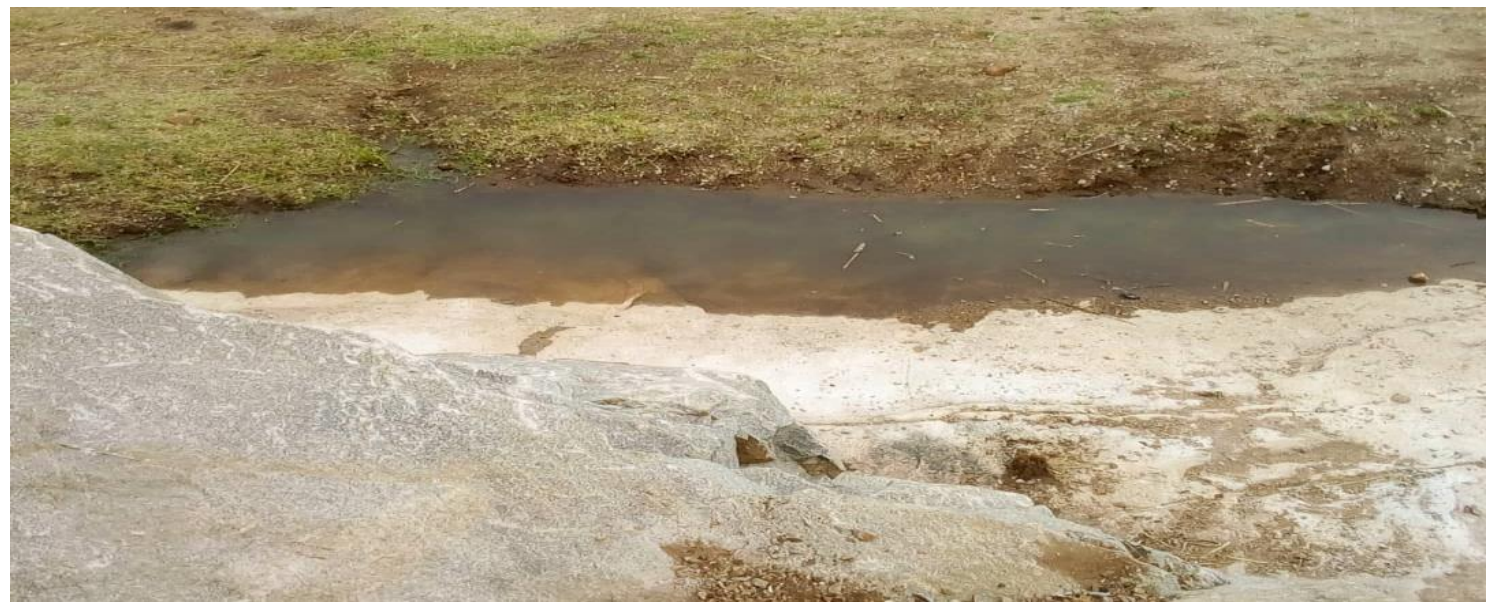

The study revealed that quarrying activities have created man-made quarry caves some of which were reported by residents to have accidentally buried people at quarry sites (as shown in Plate 3). The cave roofs collapse on their weight forming sinkholes and the people found quarrying in the caves usually do not survive. It was reported by 50 respondents (Table 1) that of the 4-5 caves formed 2-3 usually collapse every year.

$100 \%$ of the people living at and near Tororo main quarry reported that the noise and air pollution

7 | This work is licensed under a Creative Commons Attribution 4.0 International License. 
emanating from the quarry were becoming immense (Table 1 and Figure 2). This was felt more by the people living on the quarry side site of the hills being quarried. The dust comes from the excavation, haul roads and from blasting (crushing) while the noise comes from the beat rhythm and pitch from earth moving and processing, and blasting equipment. This is worsened when prevailing winds blow across the quarry site towards residencies of people sweeping dust to people for a distance between $1-5 \mathrm{~km}$ and $100 \mathrm{~m}$ high. This has not only affected the ambient atmospheric air quality of Tororo but also affected human health (respiratory and sight diseases) in the long run.

Plate 3: part of the quarry site in Petta where 2 people were buried by collapsing cave in 2020

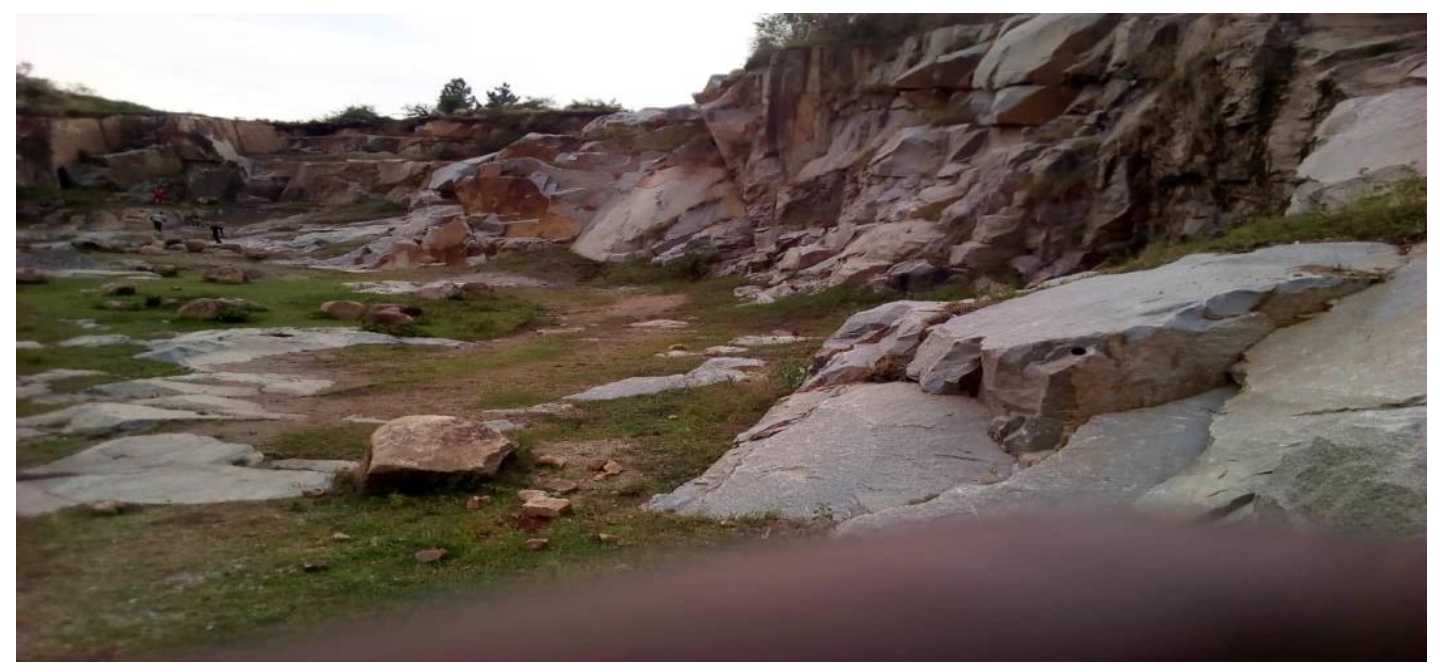

On the other hand, quarrying has created habitats for biota. The man-made caves left behind after abandonment of some quarry site points have been occupied by many species of bats such as nectar feeding and insectivorous bats. Depressions filled with rain water forming seasonal ponds have been occupied by aquatic macroinvertebrates and endemic fish species such as Barbus palludinosus thereby creating new communities (ponds, mosquitoes, and other macroinvertebrates and fish).
Monkeys were also found to enjoy (inhabit) these caves.

\section{Socio-economic Impact Assessment of Stone Quarrying in Tororo District}

Our study revealed that stone quarrying in Tororo district has caused both costs and benefits, but on a balance, the socio-economic benefits outweighed the costs. These were summarized in Table 2.

Table 2: Socio-economic impact assessment of stone quarrying in Tororo district

\begin{tabular}{lll}
\hline Response & No. of respondents & \% of total population \\
\hline Benefits & & \\
\hline Employment opportunities & 200 & 100 \\
Standard of living enhancement & 158 & 79 \\
Revenue generation for local government & 129 & 65 \\
Social amenities & 42 & 21 \\
Small scale trade & 97 & 49 \\
\hline Costs & & \\
\hline Labour competition & 117 & 59 \\
Accidents at quarry sites & 78 & 39 \\
Child labour and school dropouts & 59 & 30 \\
Escalation of HIV prevalence. & 73 & 37 \\
\hline
\end{tabular}

$8 \mid$ This work is licensed under a Creative Commons Attribution 4.0 International License. 
Figure 3: Socio-economic impact assessment of stone quarrying in Tororo district

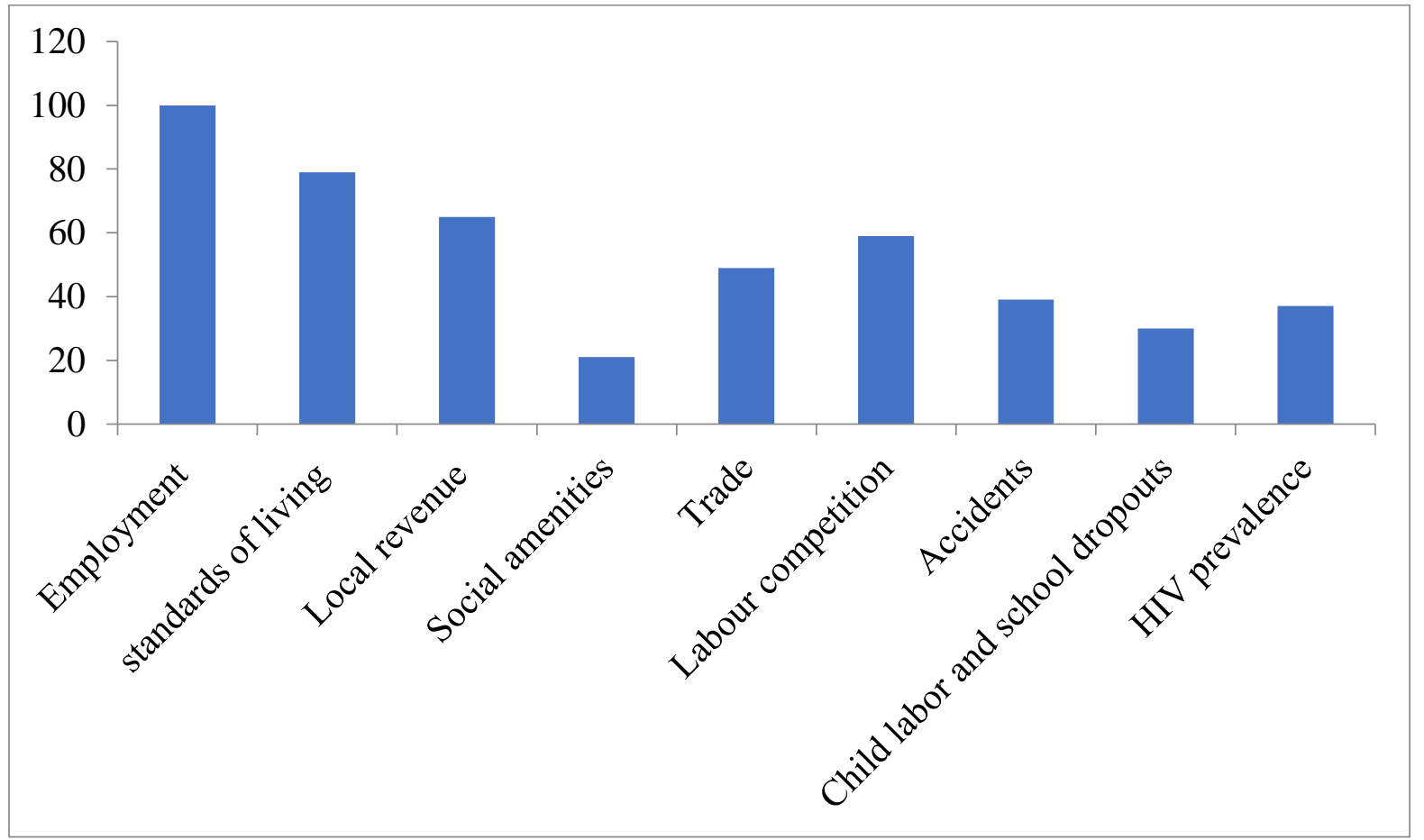

The study indicated that quarrying is a source of employment opportunities. This was revealed by $100 \%$ of the respondents (Table 2 and Figure 3). Petta quarry site alone which is an artisanal site where most of the work is manual employs approximately 160 workers. Men do more masculine work including wedging and breaking of rocks into smaller blocks as indicated in plate 4 . Transportation of final products to the market where products are demanded using trucks is also done by men. Women and children do the finishing work of breaking blocks into small aggregates of different sizes including 1 inch, $1 / 2$ inch and $1 / 4$ inch. There were more females than males employed in the Petta quarry site than Tororo main quarry. Over $80 \%$ of the people employed are born in Tororo district while the rest come from surrounding districts of Mbale, Busia and Butaleja. At Tororo main quarry site, much of the work is mechanized since it is more commercial site. The people employed are skilled who do machine operation doing excavation, drilling and surveying. In general, it was discovered that remunerations and incomes of people working in quarry sites in Tororo ranged between USD 100 -500 per month depending on the demand.
158 respondents (Table 2 and Figure 3) indicated that, resorting to stone quarrying has come as a result of demand for enhancement of standards of living (sanitation, housing) by the people of Tororo. Stones have been demanded people in local villages and but mostly in surrounding towns for construction of self-contained houses where stones (hard core) are used for construction of sock-pits and house foundations, or wall and floor tiles as well as road construction.

Stone quarrying has generated revenue for Tororo district for now over 50 years. Every tone of black igneous rocks from Petta quarry site sold at Ug Shs 180000 is charged USD 5 while that of other rock types is levied USD 3. The levies are charged by the district local council authorities. Mining companies such as LAFARGE for Tororo cement pays annually to the Uganda Revenue Authority that re disburses the revenue back to the district treasury through rightful and lawful channels.

Social amenities such as murram roads have been constructed connecting quarry sites to major roads and major towns. Although most of these roads are not surveyed and well maintained, they have

9 | This work is licensed under a Creative Commons Attribution 4.0 International License. 
improved on the connectivity and accessibility of the villages where they have been constructed.

The study revealed stone quarrying in Petta Sub County has contributed to the development of trade and commerce. The respondents agree that the market from the quarry sustains the trading centres established within the quarry fringes like Achongi and Makauri trading centres both in Petta parish. Small scale vendors from different parts of the district dealing in merchandise including clothes and food items like half-cakes ("mandazi"), ripe banana, fried cassava have found a market within the quarry sites. Such activities broaden the income base of the people, thereby, helping reduce poverty levels. $45 \%$ of the interviewed villagers (Table 2) said that they were involved in various vending activities at the quarry sites

97 respondents accounting for $21 \%$ of the total respondents indicated that quarrying in Petta has resulted in the development of infrastructure. The study found out that access roads inform of dry weather roads are connecting the quarry centres to the nearest all weather roads. The study also found out that at Petta Ayago, there is a trace of a railway line that connected the quarry at Petta to the Tororo - Nagongera railway line

On the other hand, stone quarrying has also removed some of the able-bodied men from the agricultural fields to the quarry sites, thereby creating labour shortage for peasant agriculture. This has left women and children to attend to the fields and thus, in many cases, further reducing traditionally low yields (Figure 3). The income from stone quarrying is not always able to offset the reduced agricultural yields thereby, in such instances, compromising food security. Forty percent of interviewed villagers confirmed that stone quarrying had compromised labour supply on the fields. This leaves women, children, and the elderly, often referred to as vulnerable groups, to take charge of the responsibility of producing food, with obvious consequences on food security for affected families.

The study indicated that stone quarrying in Petta quarry site results in accidents during rock breaking and transportation. $39 \%$ of the respondents revealed that quarrying in Petta Sub County is related with accidents. The respondents pointed out that the accidents range from minor bruises to serious accidents like loss of eyes or amputation of fingers as a result of working tools like hammering the hands and flying rock pieces during rock breaking process. Some caves formed by man as a result of quarrying usually collapse on their weight and burry quarry workers leading to loss of lives. Considering the fact that compensation to such workers is reportedly insignificant, the social implications for the dependents of affected workers are easily discernible. Injured and ill workers are no longer able to look after their families, while other families have lost sole breadwinners, thereby widening the margin of poverty for such families.

The respondents also pointed out that quarrying in Petta has accelerated school dropout rates and increased the level school absenteeism. In the respondents' argument, the income earned from quarrying lures the pupils and students from the quarrying areas into absenteeism and prolonged absenteeism results into dropping out. This was revealed by 59 respondents accounting for $30 \%$ of the respondents. The study also established that quarrying has encouraged the use of child labour below the age of 18. Exposing such children to the tedious work puts their growth and development at stake and they may experience the effects in the future. The study indicated that $7.7 \%$ of the workers are children hence child labour is wide spread

Among the social costs of stone quarrying is the increase in prostitution around quarry sites involving quarry workers, vendors, and villagers. HIV/AIDS prevalence has reportedly increased with the establishment and expansion of quarrying operations in these areas. An increase in HIV/AIDS orphans and single mothers in the areas also points to the above problem. Some of the quarry workers come from as far as Mbale, Butaleja, Bugiri, busia and Iganga and would have left behind their families. Forty-five percent of the interviewed workers coming from outside Tororo District were married and left their spouses behind. Such spousal separation exposes the people to infidelity, thereby enhancing the spread of HIV/AIDS. 


\section{DISCUSSION}

\section{Environmental Impact Assessment of Stone Quarrying in Tororo District}

Stone quarrying came with terrestrial ecosystem degradation this was done by removing vegetation cover to unearth the rocks for quarrying which was followed by destruction of biota and biota micro habitats. This affected monkeys and macroinvertebrates that ended up migrating. This was not intentional but rather erroneous. This study therefore is in consonance with (Enger and Smith, 2002), who noted that. As rock is removed by quarrying, some terrestrial habitats are destroyed along. The habitat provided by the caves, soil and vegetation will cease to exist. Animals that that are mobile and able to find new homes, might survive; the rest will die.

In the current study, Water quality deterioration was attributed to stone quarrying since the activity came with increased sedimentation of wells and springs where local people abstract water for domestic use. This agrees with Asaad and Jordan (1994) who maintained that measures must be taken to control runoff, sedimentation from quarry sites to surface water sources to avoid deterioration of ground water. Our current study however disagrees with that of Moore and Hughes (1979) who discovered that there was no relationship between blasting of stone and quality of water in wells. This is because of differences in the rock types and precautions taken during and before quarry activities start. In our study sites especially Petta quarry site, EIA was not required and this is where the problem was most felt.

Scenery deformation of relief through stone quarrying is not a new phenomenon and not peculiar to Tororo hills. Similar scenarios were reported by (Langer and Kolm, 2001) to have happened in the United States where, Pockets of small and large gaping holes associated with quarrying activities not only destroyed the aesthetic beauty of the landscape but also become suitable breeding grounds for mosquitoes when rainwater collected in them.

The anticipation that stone quarrying in Tororo could have resulted into drying up of wells and springs, further wilting of grass and trees in the surrounding areas is a similar complaint that was raised in United States of America, where rock quarries penetrate the water table, and the nearby landscapes were commonly dewatered and water table was lowered as reported by (Langer and Kolm, 2001). The difference here is that while in USA the quarries were of Karst landscape, in Tororo; this has also been found in the igneous rock formations.

The study revealed that quarrying activities have created man-made quarry caves some of which were reported by residents to have accidentally buried people at quarry sites. The cave roofs collapse on their weight forming sinkholes and the people found quarrying in the caves usually do not survive. It was reported that of the 4-5 caves formed 2-3 usually collapse every year. The same phenomenon was reported by (Gunn and Gagen, 1987) where Quarrying was associated with the removal of stone, which results in the destruction of habitat including relict and active caves and natural sinkholes

The same source of dust and noise reported by people living near Tororo main quarry site was explained by Enger and Smith (2002), who indicated that, during blasting drilling and crushing of rock materials, a large amount of dust is blown into the atmosphere to the discomfort of residents. This comes with ailment especially those related to respiratory system of humans. (Howard and Cameron, 1998) too reported that, one of the most frequent com-plaints the public makes to the crushed stone industry situated near population centres are about blasting noise and that blasting may occur daily or as infrequently as once or twice a year. In our current study, quarrying takes place throughout the year with the same effects and magnitude increasing with direction of prevailing winds

According to Langer and Kolm (2001), caves that develop in quarry mines form one of the most peculiar terrestrial ecosystems. They are filled with rain water and are associated with lack of light, a habitat that is preferred by some specific mammals especially bats. In our study, the sinkholes and caves that formed were filled with rain water forming seasonal ponds that were occupied by some endemic fish species and macroinvertebrates which were observed while in the field. There was also evidence of monkeys spending nights in these caves. 


\section{Socio-Economic Impact Assessment of Stone Quarrying in Tororo District}

Kalu et al. (2018) observed that, for granite to get to market desired structures, it involves lot of processes which are labour intensive thereby employing people. This advantage of employment spills over to this similar activity in Tororo district of Uganda where a total of 497 men and women are employed in stone quarrying earning income that they use to improve their standards of living. The people employed are fewer skilled personnel and majority is unskilled earning between USD 100-500 per month as of May 2021 depending on the work type done at site. In Ghana, Asante et al. (2014) observed that, the average monthly contribution of quarrying to household incomes, about 68 per cent and 56 per cent of respondents in Nkukua Buoho and Ntiri Buoho respectively earn between $\mathrm{GH} \phi 50$ to 299 monthly as of 2013.

Unlike in Zimbabwe where the quarrying sector plays a key role in terms of foreign exchange, gross domestic product (GDP), government revenue, and capital formation (Chenje et al., 1998), in Uganda, the GDP, revenue and capital generation from stone quarrying is limited to a local scale (almost at individual or district level). This is because the capital invested and extent of quarrying and demand are commensurate to the output.

Quarrying in Zimbabwe has been influential in the infrastructural development of the country. It has come with basic infrastructure such as water, communication, health, education, electricity. The country is linked by roads, railways, and other communication links (Viewing, 1984) connecting a series of quarry stations. In the current study, though not well surveyed and maintained, quarry sites have led to construction of feeder roads connecting villages to main roads that are used by local communities for transporting agricultural commodities to trading centres and tons like Tororo municipality.

According to Tanyaradzwa (2010), black granite quarrying has also brought with it some costs to Mutoko district of Zimbabwe including creation of labour bottlenecks for peasant agriculture. This is in consonance with the current study where we discovered that some of the able-bodied men have shifted from the agricultural fields to the quarry sites, thereby creating labour shortage for peasant agriculture. This has left women and children to attend to the fields and thus, in many cases, further reducing traditionally low yields. The income from stone quarrying is not always able to offset the reduced agricultural yields thereby, in such instances, compromising food security.

Stone quarrying in Petta quarrying site was reported to claim 15 people annually who are buried in the collapsing quarries. These are however fewer when compared to 427 workers who perished underground at Wankie Colliery quarry when the quarry roof collapsed in one day morning shift June 1972 as reported by Eaton (1996). This has made this activity a risky venture. People would vacate this activity but because of lack of better alternative sources of income, they stay.

\section{CONCLUSION}

Based on our study's environmental impact assessment results, it can be concluded that stone quarrying has done more harm than good to the biophysical environment of Tororo district where, water quality and terrestrial ecosystems have been degraded beyond recovery, scenic beauty of the relief has been deformed and communities living near the Tororo main quarry have day and night braved the noise and dust from the quarry site resulting into diseases relating to sight and respiration.

On the other hand, socio-economic benefits resulting from stone quarrying outweighed the negative impacts the activity had on the well-being of Tororo district. The activity has reduced on the unemployment pressure/ burden of the district thereby enhancing their standards of living even though many have lost their lives in collapsing caves and because many have run to the activity, agriculture has been left to the young and elderly causing food shortage.

It was recommended that; the district community development office upgrades the activity at Petta quarrying site by giving a financial support to the small-scale quarry individuals which they can use to purchase better quarrying equipment. This will improve on the quality and quantity of the quarry 
stone hence higher incomes and economic development.

On the other hand, the district environment office of Tororo should monitor the quarrying activities to avoid leaving open pits and caves that are dangerous to lives of people at quarry sites. These open pits should be back-filled especially in parts where quarrying has ceased. This will restore the scenic beauty of the areas in question.

\section{ACKNOWLEDGMENT}

We are thankful to the Department of Geography Busitema University who funded this project through small departmental research funds. We are also grateful to the Petta quarrying community who gave us the information we needed that has given this study a shape.

\section{REFERENCES}

Asante, F., Abass, K., \& Afriyie, K. (2014). Stone quarrying and livelihood transformation in PeriUrban Kumasi.

Assad, E. A. and Jordan, H. (1994). Karst terraces and Environmental aspects, journal of Environmental Geology, 23: 228-237.

Birabwa, E. (2006). Small-Scale Stone Quarrying: Its Contribution to People's Livelihoods.: A Case Study Kasenge Parish, Nama Sub-County, Mukono District (Uganda) (Master's thesis, Geografisk institutt).

Chenje, M., Sola, L., \& Paleczny, D. (1998). The state of Zimbabwe's environment 1998.

Kalu, E. (2018). Environmental Impact of Stone Quarrying Activities in Ebonyi State, Nigeria. $J$ Advanced Studies in Agric, Biological and Environ Sci, 5(2), 7-22.

Eaton, A. J., Ncube, B., Piha, M., \& Reeler, B. (1996). Opencast mine reclamation in Wankie Colliery with particular reference to land rehabilitation and revegetation.

Engers, E. D., \& Smith, B. F. (2002). Environmental Science: A study of interrelationship.
Gunn, J. and Gagen, P. (1987). Proceeding of Engineering and Environmental Applications: The second multi-disciplinary conference on sinkholes and the environmental impacts of karst. 20-24 November, London

Howard, B., \& Cameron, I. (1998). Dust control: Best Practice Environmental Management in Mining. Environment Australia.

Brajesh, J. (2006). Rural non-farm employment in India: Macro-trends, micro-evidences and policy options. Delhi: Agricultural Economics Unit, Institute of Economic Growth.

Langer, W. H. (2001). Potential environmental impacts of quarrying stone in karst: a literature review. US Department of the Interior, US Geological Survey.

Makuvaro, V., Walker, S., Munodawafa, A., Chagonda, I., Murewi, C., \& Mubaya, C. (2017). Constraints to crop production and adaptation strategies of smallholder farmers in semi-arid central and western Zimbabwe. African Crop Science Journal, 25(2), 221-235.

Mwangi Aamuel Njoroge (2014). An assessment of environmental impacts of quarrying activities in Ndarugo area, Kiambu County (Unpublished dissertation).

Moore, J. D., \& Hughes, T. H. (1979). Effect of Quarry Blasting on Ground-Water Quality in a Limestone Terrane in Calhoun County, Alabama.

Ogwang T, Vanclay F. Social Impacts of Land Acquisition for Oil and Gas Development in Uganda. Land. $\quad 2019 ; \quad$ 8(7):109. https://doi.org/10.3390/land8070109

Tanyaradzwa, C. (2010). An assessment of the benefits and costs of black granite quarrying in Mutoko District, Zimbabwe: A socio-cultural, biophysical and economic approach. Journal of Sustainable Development in Africa, 12(3), 324336.

Thomson, J. G., \& Purves, W. D. (1978). A guide to the soils of Rhodesia. A guide to the soils of Rhodesia. 
East African Journal of Environment and Natural Resources, Volume 4, Issue 1, 2021

Article DOI: https://doi.org/10.37284/eajenr.4.1.445

Viewing, K. (1984). Mining and the Development of Zimbabwe. Chamber of Mines Journal, 8(2), 21-51.

Wells, J. (2000). Environmental concerns and responses in small-scale stone quarries in Nairobi. Enterprise development \& microfinance, 11(2), 28-38.

14 | This work is licensed under a Creative Commons Attribution 4.0 International License. 